\title{
New records of the southern naked-tailed armadillo Cabassous unicinctus unicinctus Linnaeus, 1758 (Cingulata: Dasypodidae) in Brazil
}

\author{
Teresa Cristina da Silveira Anacleto ${ }^{1,4}$, Leandro Perez Godoy ${ }^{2}$ \& Darius Pukenis Tubelis ${ }^{3}$ \\ ${ }^{1}$ Laboratório de Mamiferos, Departamento de Biologia, Universidade do Estado de Mato \\ Grosso-UNEMAT, CEP 78690-000, Nova Xavantina, MT, Brasil \\ ${ }^{2}$ Laboratório de Mamíferos, Departamento de Ciências Biológicas, Escola Superior de Agricultura "Luiz \\ de Queiroz”, Universidade de São Paulo - USP, CEP 13418-900, Piracicaba, SP, Brasil \\ ${ }^{2}$ Departamento de Ciências Animais, Universidade Federal Rural do Semi-Árido - UFERSA, \\ CEP 59625-900, Mossoró, RN, Brasil \\ ${ }^{3}$ Corresponding author: Teresa Cristina da Silveira Anacleto,e-mail: teresacristina@unemat.br
}

ANACLETO, T.C.S., GODOY, L.P. \& TUBELIS, D.P. New records of the southern naked-tailed armadillo Cabassous unicinctus unicinctus Linnaeus, 1758 (Cingulata: Dasypodidae) in Brazil. Biota Neotrop. 13(2): http://www.biotaneotropica.org.br/v13n2/en/abstract?short-communication+bn00213022013

\begin{abstract}
The geographic distribution of Cabassous unicinctus is poorly known due to the low number of available records. Two subspecies with distributions limited by the Amazonas River were recognized in 1980. Cabassous u. unicinctus has been found north of this river, while C. u. squamicaudis occurs in areas south of the river. This study aimed to update the distribution records of C. u. unicinctus in Brazil. We compiled records from literature, museum collections and field studies. New records of this subspecies were obtained from the Brazilian states of Acre, Pará, Rondônia and Mato Grosso. These records enlarge a geographic distribution of C. u. unicinctus to Amazonian and Cerrado biomes, regions located south of the Amazon River.

Keywords: Xenarthra, geographic distribution, armadillo, Amazonas, Cerrado, Mato Grosso.
\end{abstract}

ANACLETO, T.C.S., GODOY, L.P. \& TUBELIS, D.P. Novos registros do tatu-de-rabo-mole Cabassous unicinctus unicinctus Linnaeus, 1758 (Cingulata: Dasypodidae) no Brasil. Biota Neotrop. 13(2): http://www. biotaneotropica.org.br/v13n2/pt/abstract?short-communication+bn00213022013

Resumo: A distribuição geográfica de Cabassous unicinctus é pouco conhecida devido ao baixo número de registros disponíveis. Foram reconhecidas na década de 1980 duas subespécies, sendo as distribuições limitadas pelo Rio Amazonas. Cabassous u. unicinctus tinha sido encontrado ao norte do rio, enquanto C. u. squamicaudis foi encontrado em áreas ao sul deste rio. Este estudo visa atualizar os registros de distribuição de C. u. unicinctus no Brasil. Nós compilamos registros de literatura, coleções de museus e estudos de campo. Novos registros dessa subespécie foram obtidos nos seguintes estados brasileiros: Acre, Pará, Rondônia e Mato Grosso. Esses registros ampliam a distribuição geográfica de C. u. unicinctus nos biomas Amazônia e Cerrado, em regiões localizadas ao sul do Rio Amazonas.

Palavras-chave: Xenarthra, distribuição geográfica, tatu, Amazonas, Cerrado, Mato Grosso. 


\section{Introduction}

Armadillos of the genus Cabassous Mc Murtrie, 1831 are widely distributed, occurring from southern Mexico to Argentina (Wetzel et al. 2007, CONABIO). Four species are currently recognized: C. centralis (Miller, 1899), C. chacoensis Wetzel, 1980, C. unicinctus (Linnaeus, 1758) and C. tatouay (Desmarest, 1804). This genus is the second largest in number the species, surpassed by the Dasypus genus. Members of this genus have carapace very flexible with a variable number of movable bands (usually eleven), and a rounded tail that may be unarmored or partially armored with scattered, small scutes and scales (Wetzel 1980, 1985). The naked tail distinguishes this genus from all other armadillos (Eisenberg \& Redford 1999).

All four species of Cabassous are threatened by illegal hunting and the permanent issue of habitat degradation in countries such as Brazil (Aguiar \& Fonseca 2008). In addition to these negative factors, there are problems related to mis-identifications of holotypes and the provenance of some Cabassous specimens deposited in museum collections. The specimen from British Museum - Natural History BMNH 55.8.28.7 is syntype, not holotype and "St. Catherine's" may be French Guiana (Sainte Catherine) or Brazil (Santa Catarina), see more problems in Cabrera (1958), Wetzel (1980) and Wetzel et al. (2007).

The only taxonomic review of this genus was done by Wetzel (1980). Using qualitative comparisons and statistical analyses, this author reorganized the confusing taxonomy and grouped the numerous synonyms into four species, distinguished two subspecies within C.unicinctus and provided a map detailing their distribution, including point localities for C. u. unicinctus (Linnaeus, 1758) and C. u. squamicaudis (Lund, 1845). The two subspecies were separated by these characters: C. u. unicicinctus has a larger body and cranium, fewer scutes on the cephalic shield, cheek below eye without scales or with few scales, naked posterior face of pinna and fewer scales on the tail. Otherwise, $C$. u squamicaudis has a small body and cranium, more scutes on the cephalic shield, more scales on cheeck, posterior side of pinna and on the tail. However, Wetzel (1980) did not examine any C.u.unicinctus from Brazil.

Few studies have plotted the distribution records of these two subspecies on maps (Wetzel 1980, 1982, 1985). According to the information published nearly thirty years ago, Cabassous u. unicinctus appears to be restricted to northern South America, encompasses the east of the Andes, including the Guyanas, Venezuela, Colombia, Ecuador and Peru, with its southernmost occurrence limited by the Amazonas River, north of the Brazil. Wetzel (1980, 1982) described this river as a zone of integration of this subspecies with C. u. squamicaudis, which occurs south of the Amazonas River.

This paper provide records of C. u. unicinctus in north of Brazil (Acre, Pará and Rondônia states) and the firsts records in central Brazil (Mato Grosso state). These records extend the known range of the species approximately $1,000 \mathrm{~km}$ away from the previously known geographic distribution, including Cerrado biome.

\section{Material and Methods}

We compiled data points from live animals captured by field researchers between 2006 and 2011 and from animals housed in the following collections: National Institute of Amazonian Research (Instituto Nacional de Pesquisa Amazônica - INPA), Museum of Zoology of the University of São Paulo (MZUSP), National Museum of Natural History (NMNH) and American Museum of Natural History (AMNH). As recognition of data points of animals found in the AMNH and NMNH collections were based on citations of localities on specimen labels, the geographical coordinates of these points were obtained from the gazetteer produced by Gardner (2007). Coordinates of other data points were indicated by the collectors or obtained by investigators during more recent field work. All data points were imported into a GIS platform (Arc View) to generate a distribution map of C. u. unicinctus.

The identification of the specimens was based on external diagnostic traits of the species cited by Wetzel (1980), including: scutes of the cephalic shield $(37 \pm 4.1 \mathrm{n}=8)$, cheek below eye without scales or with few scales, naked posterior face of pinna and fewer scales on the tail. Some external measurements were taken from specimen labels of five armadillos (Table 1). Another distinctive characteristics used in this study is the carapace sharply marked laterally by a buffy border, as well as a rosaceous snout and abdomen; these body regions are darker in C. u. squamicaudis. Only two other armadillo species have a carapace with a buffy border: the northern naked-armadillo (C. centralis Miller, 1899) and the giant armadillo (Priodontes maximus Kerr, 1792).

\section{Results and Discussion}

We compiled 16 records of C. u. unicinctus in the Neotropical region (Table 2). The specimens found in the collections of AMNH $(\mathrm{n}=4)$ and NMNH $(\mathrm{n}=2)$ are the same as those analyzed by Wetzel (1980) in his revision of the genus Cabassous (Figure 1). These records were limited to the northern region of South America (Venezuela, Guyana and Peru). Other specimens found in museums were collected in the Brazilian states of Acre $(n=1$, INPA) and Pará $(\mathrm{n}=1$, MZUSP).

Eight other records involve photos of animals found in the states of Pará, Mato Grosso and Rondônia: 1) two road-killed armadillos from the states of Rondônia (Cacoal) and Pará (Santarém); 2) one individual hunted by sustainable indigenous people in the Tapirapé Indigenous Land, in Confresa, Mato Grosso; 3) five armadillos that were captured and released in Pará (Paraupebas), Rondônia (Porto Velho and Chupinguáia) and Mato Grosso (Paranaíta and Lucas do Rio Verde) (Table 2).

Cabassous armadillos are poorly represented in collections. To review the genus, Wetzel (1980) analyzed 176 specimens housed in the major collections of the world. He visited 34 institutions in 14 countries. His work involved the examination of 37 specimens of $C$. u. squamicaudis, of which only two animals were not from Brazil. Furthermore, all 41 analyzed specimens of C. u. unicinctus were from

Table 1. External measurements (in mm) of Cabassous u. unicinctus. American Museum of Natural History - AMNH, National Museum of Natural History - NMNH, Instituto de Pesquisas da Amazônia - INPA and Museum of Zoology - University of São Paulo - MZUSP.

\begin{tabular}{|c|c|c|c|c|c|c|}
\hline Identification & Head + body & Ear & Tail & Foot & Sex & Weight, kg \\
\hline NMNH 253986 & 498 & - & 192 & 73 & $\mathrm{M}$ & - \\
\hline NMNH 296613 & 400 & - & 173 & 79 & M & - \\
\hline AMNH 98459 & 285 & 30 & 165 & 90 & M & - \\
\hline INPA 2861 & 355 & 36 & 172 & 76 & $\mathrm{~F}$ & 2.00 \\
\hline MZUSP MB5 & 380 & 39 & 165 & 74 & M & 3.60 \\
\hline
\end{tabular}




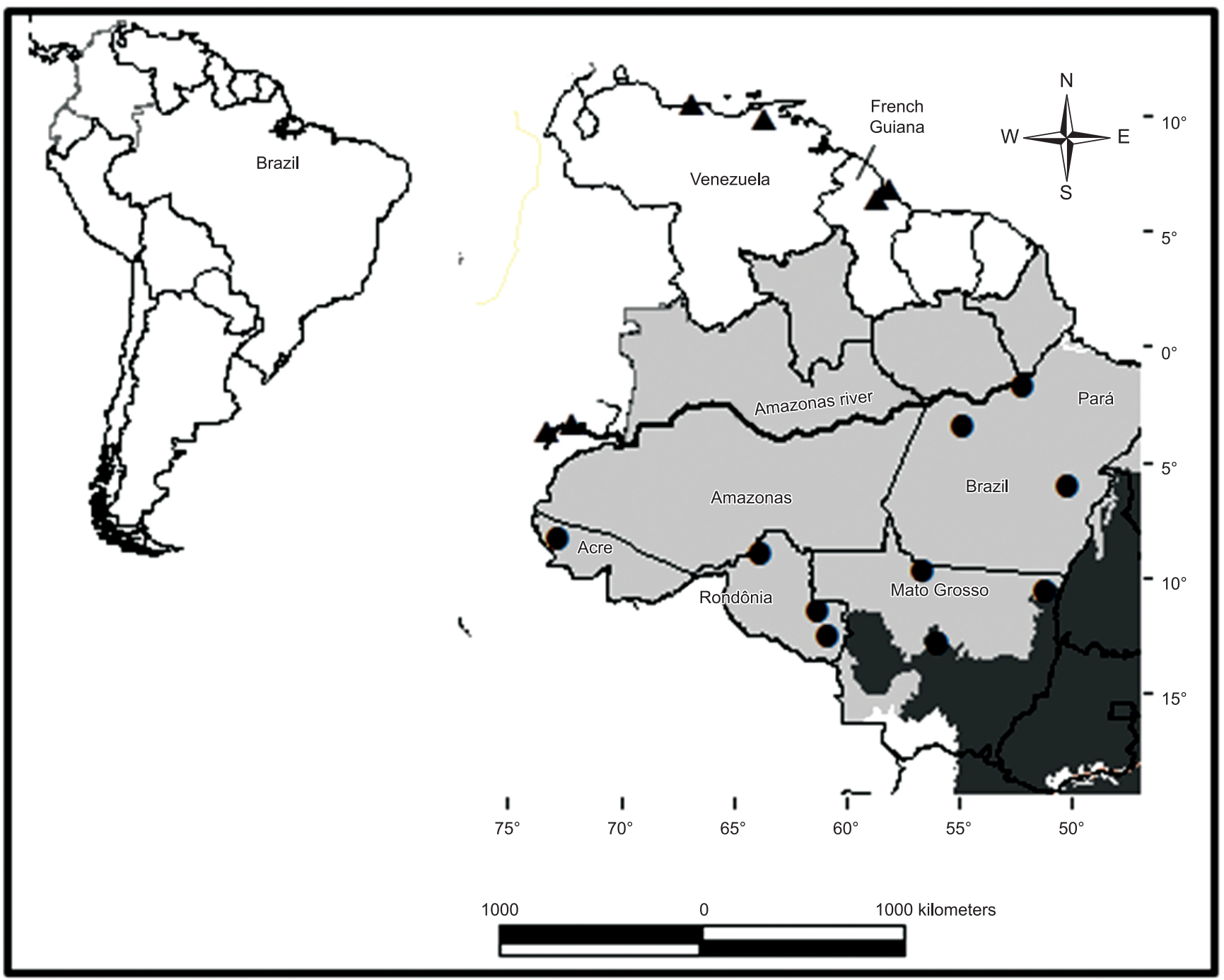

Figure 1. Distribution of Cabassus u. unicintus with 6 records examined for Wetzel (1980), from American Museum of Natural History and National Museum of Natural History $(\boldsymbol{\Delta})$, and new records compiled by this study $(\bullet)$. Biomes Amazon ( $\square$ ) and Cerrado $(\boldsymbol{\bullet})$.

Table 2. Records of Cabassous u. unicinctus, with information on the location, geographic coordinates, type of records and identification of collection material and contributors of unpublished data. American Museum of Natural History - AMNH, National Museum of Natural History - NMNH, Instituto de Pesquisas da Amazônia - INPA and Museum of Zoology - University of São Paulo - MZUSP.

\begin{tabular}{|c|c|c|}
\hline Country / Locality & Geographic coordinates & Type of records / identification \\
\hline Venezuela / San Julian & $10^{\circ} 28^{\prime} \mathrm{S} 66^{\circ} 52^{\prime} \mathrm{W}$ & NMNH 253986 \\
\hline Venezuela / Monagas, Caiçara & $09^{\circ} 49^{\prime} \mathrm{N} 63^{\circ} 36^{\prime} \mathrm{W}$ & NMNH 296613 \\
\hline British Guyana / Georgetown & $06^{\circ} 48^{\prime} \mathrm{N} 58^{\circ} 10^{\prime} \mathrm{W}$ & AMNH 207370 \\
\hline British Guyana / Kartabo & $06^{\circ} 23^{\prime} \mathrm{N} 58^{\circ} 41^{\prime} \mathrm{W}$ & AMNH 142994 \\
\hline Peru / Loreto, Iquitos & $03^{\circ} 46^{\prime} \mathrm{S} 73^{\circ} 15^{\prime} \mathrm{W}$ & AMNH 98459 \\
\hline Peru / Loreto, Orosa & $03^{\circ} 26^{\prime} \mathrm{S} 72^{\circ} 08^{\prime} \mathrm{W}$ & AMNH 74113 \\
\hline Brazil / Acre, Cruzeiro do Sul (Juruá River) & $08^{\circ} 22^{\prime} \mathrm{S} 72^{\circ} 49^{\prime} \mathrm{W}$ & INPA 2861 \\
\hline Brazil / Pará, Parauapebas & $06^{\circ} 03^{\prime} \mathrm{S} 50^{\circ} 10^{\prime} \mathrm{W}$ & Photo/ Karla Leal \\
\hline Brazil / Pará, Santarém (Br 163) & $03^{\circ} 34^{\prime}$ S $54^{\circ} 52^{\prime} \mathrm{W}$ & Photo/ Herbert S. Soares \\
\hline Brazil / Pará, Porto de Moz (Xingu River) & $01^{\circ} 44^{\prime}$ S $52^{\circ} 14^{\prime} \mathrm{W}$ & MZUSP- MB5 \\
\hline Brazil / Rondônia, Cacoal (Br 364) & $11^{\circ} 32^{\prime} \mathrm{S} 61^{\circ} 18^{\prime} \mathrm{W}$ & Photo/ Sérgio G. Silva \\
\hline Brazil / Rondônia, Porto Velho & $08^{\circ} 45^{\prime} \mathrm{S} 63^{\circ} 54^{\prime} \mathrm{W}$ & Photo/ Leandro P. Godoy \\
\hline Brazil / Rondônia, Chupinguáia & $12^{\circ} 32^{\prime} \mathrm{S} 60^{\circ} 54^{\prime} \mathrm{W}$ & Photo/ Leandro P. Godoy \\
\hline Brazil / Mato Grosso, Confresa & $10^{\circ} 39^{\prime} \mathrm{S} 51^{\circ} 17^{\prime} \mathrm{W}$ & Photo/ Herbert S. Soares \\
\hline Brazil / Mato Grosso, Paranaíta & $9^{\circ} 40^{\prime} \mathrm{S} 56^{\circ} 28^{\prime} \mathrm{W}$ & Photo/ Leandro P. Godoy \\
\hline Brazil / Mato Grosso, Lucas do Rio Verde & $13^{\circ} 03^{\prime} \mathrm{S} 55^{\circ} 55^{\prime} \mathrm{W}$ & Photo/ Leandro P. Godoy \\
\hline
\end{tabular}


regions outside of Brazil and the specimen AMNH 95298, from Pará state, was considered as C. u. squamicaudis, although the external characters are the C. u. unicinctus.

The distribution of C. u. unicinctus proposed by Wetzel (1980, 1982) encompasses an area east of the Andes and north of the Amazon, including the Guyanas and parts of Brazil, Venezuela, Colombia, Ecuador and Peru. In Brazil, its distribution is restricted to regions located north of the Amazonas River. This river is described as a zone of integration of this subspecies with $C . u$. squamicaudis, which occurs south of the Amazonas River (Wetzel 1980, 1982). However, there is no explanation of how this zone of integration was established.

With the exception of Wetzel's investigations (1980, 1982, 1985), no studies provided morphological characteristics or maps that show the geographic distribution of C. u. unicinctus and C. u. squamicaudis. Recently, Smith et al (2011) documented the first specimens of Cabassous u. squamicaudis from Paraguay. The available information most often refers to $C$. unicinctus with a morphological description of one of the two subspecies, with maps that show the wide distribution of C. unicinctus (Emmons \& Feer 1990, Eisenberg \& Redford 1999, Gardner 2007, Aguiar \& Fonseca 2008).

The information compiled in our study indicates that the range of C. u. unicinctus goes beyond the Amazon River, reaching the states of Mato Grosso, Pará and Rondônia. Most of our records $(n=8)$ that were found south of this river occurred in the Amazonian region. On the other hand, we obtained a record in Confresa (Mato Grosso), which lies in a transition area between the Amazon and Cerrado biomes. Another record outside the Amazon region occurred at Lucas do Rio Verde, a Cerrado locality in Mato Grosso, and involved an armadillo using forested areas along the margins of the Verde River. This record expands the known range of occurrence of C. u. unicinctus to a biome other than the Amazon, in an area located about 1,000 km away from the previously known geographic distribution. Probably this species was always there and never had been recorded.

The potential distribution of $C$. unicinctus predicted a wide range in Brazil, including the Amazon and the Cerrado (Anacleto et al. 2006). Our study confirms the real occurrence of $C$. u. unicinctus in these two biomes. Investigations that evaluated resources required by $C$. unicinctus argued that there is a restriction in the use of these habitats, and pointed out that the species is rare in forests (Encarnação 1986, Emmons \& Feer 1990). More recent studies suggest that C. unicinctus occurs in complex vegetation structures, such as forests (Bonato et al. 2008, Abba \& Superina 2010). Despite this knowledge about the species, no studies provided information on habitat preferences by the subspecies $C$. u. unicinctus. Our records in the Amazon and in forested areas in the Cerrado and ecotonal zones between these two biomes suggest that the subspecies C. u. unicinctus is restricted to forest habitats.

The compilation of records in our study shows that the knowledge on the geographic distribution of Cabassous taxa is quite little, and can change substantially with a few additional records. Further investigations are needed on the entire genus and to assess whether the two subspecies are actually to separate species.

\section{Acknowledgements}

We kindly thank researchers that gave us permission to present their unpublished records: Biologist M. Sc. Karla Leal, Veterinary
Physician Dr. Herbert S. Soares and Ecologist M. Sc. Sérgio G. Silva. We express our gratitude to Linda K. Gordon and Darrin Lunde (National Museum of Natural History - NMNH) and Eileen Westwig (American Museum of Natural History - AMNH) for providing access to the mammal collections. The manuscript was greatly improved by comments and critical reviews from two anonymous referees. This work was funded by GENPAC Project: Geographic genetic and regional planning for conservation of natural resources in the Cerrado.

\section{References}

AGUIAR, J.M. \& FONSECA, G.A.B. 2008. Conservation status of the Xenarthra. In The Biology of the Xenarthra (S.F. Vizcaíno \& W.J. Loughry, eds). The University Press of Florida, Gainesville, p.215-281.

ABBA, A.M. \& SUPERINA, M. 2010. The 2009/2010 Armadillo Red List Assessment. Edentata 11(1):35-184.

ANACLETO, T.C.S., DINIZ-FILHO, J.A.F. \& VITAL, M.V.C. 2006. Estimating potential geographic ranges of armadillos (Xenarthra, Dasypodidae) in Brazil under niche-based models. Mammalia 70(3-4):202-213.

BONATO, V., MARTINS, E.G., MACHADO, G., SILVA, C.Q. \& REIS, S.F. 2008. Ecology of the armadillos Cabassous unicinctus and Euphractus sexcinctus (Cingulata: Dasypodidae) in a Brazilian Cerrado. J. Mammal. 89(1):168-174. http://dx.doi.org/10.1644/06-MAMM-A-187.1

CABRERA, A. 1958. Catálogo de los Mamiferos de América del Sur. Rev. Mus. Argent. Cienc. Nat. Bernardino Rivadavia Inst. Nac. Invest. Cienc. Nat. 4(1):1-307.

COMISIÓN NACIONAL PARA EL CONOCIMIENTO Y USO DE LA BIODIVERSIDAD - CONABIO. Cabassous centralis. http://www. conabio.gob.mx/informacion/metadata/gis/cabcen_dcgw.xml? httpcache $=y e s \& \_x s l=/ d b /$ metadata/xsl/fgdc_html.xsl\&_indent $=$ no (último acesso em 20/01/2013).

EISENBERG, J.F. \& REDFORD, K.H. 1999. Mammals of the Neotropics. The University of Chicago Press, Chicago, v.3.

EMMONS, L.H. \& FEER, F. 1990. Neotropical rainforest mammals: a field guide. The University of Chicago Press, Chicago.

ENCARNAÇÃO, C.D. 1986. Contribuição à ecologia dos tatus (Xenarthra, Dasypodidae) da Serra da Canastra, Minas Gerais. Dissertação de Mestrado, Universidade Federal do Rio de Janeiro, Rio de Janeiro.

GARDNER, A.L. 2007. Mammals of South America. Marsupials, Xenarthrans, Shrews and Bats. The University of Chicago Press, Chicago.

SMITH, P.A., OWEN, R.D., ATKINSON, K., CASTILlO, H. \& NORTHCOTE-SMITH, E. 2011. First records of the southern nakedtailed armadillo Cabassous unicinctus (Cingulata: Dasypodidae) in Paraguay. Edentata 12(1):53-57.

WETZEL, R.M. 1980. Revision of the naked-tailed armadillos, genus Cabassous McMurtrie. Ann. Carnegie Mus. 49(1):323-357.

WETZEL, R.M. 1982. Systematics, distribution, ecology and conservation of south american edentates. In Mammalian biology in South America (M.A. Mares \& H.H. Genoways, eds). The University of Pittsburg Press, Pittsburg, p.345-375.

WETZEL, R.M. 1985. The identification and distribution of recent Xenarthra (=Edentata). In The Evolution and Ecology of Armadillos, Sloths and Vermilinguas (G.G. Montgomery, ed.). Smithsonian Institution Press, Washington, p.5-21.

WETZEL, R.M., GARDNER, A.L., REDFORD, K.H. \& EISENBERG, J.F. 2007. Order Cingulata Illiger, 1811. In Mammals of South America. Marsupials, Xenarthrans, Shrews, and Bats (A.L. Gardner, ed.). University of Chicago Press, Chicago, p.128-157. 